\title{
Are Target Serum Bicarbonate Levels Achieved in Maintenance Hemodialysis Patients: A Single Centre Experience
}

\author{
Geo Philip John, Jacob George, Noble Gracious ${ }^{*}$, Mohandas MK, Sajeev Kumar and Vineetha \\ Department of Nephrology, Government Medical College, Thiruvananthapuram, Kerala
}

Received 20 Jan 2018, Accepted 25 March 2018, Available online 30 March 2018, Vol.6 (March/April 2018 issue)

\begin{abstract}
Majority of the maintenance hemodialysis patients donot achieve the target predialysisserum bicarbonate levels. Routine monitoring of serum bicarbonate in diaysis patients is not universally done. We aimed to assess whether our dialysis population attained the predialysis serum bicarbonate target of $>22 \mathrm{mEq} / \mathrm{L}$ as recommended by the NKF-KDOQI. Correlation between predialysis bicarbonate and clinical \& biochemical parameters was also assessed. Fifty patients undergoing maintenance hemodialysis in Government Medical College, Thiruvananthapuram were included in the study.All patients received fixed non-individualizeddialysate bicarbonate concentrations. The mean predialysis bicarbonate obtained was $19 \pm 4.2 \mathrm{mEq} / \mathrm{L}$. Thirty six patients(72\%) had bicarbonate levels $<22 \mathrm{mEq} / \mathrm{L}$. Nineteen patients (38\%) had bicarbonate level $<17 \mathrm{mEq} / \mathrm{L}$ and 5 patients (10\%) had level $>25 \mathrm{mEq} / \mathrm{L}$. Majority of the patients failed to achieve the target serum bicarbonate. A negative correlation was obtained for predialysis bicarbonate levels with BMI, total protein, serum uric acid, serum phosphorus and serum ferritin. Better nutritional status may be associated with reduction in bicarbonate level because of increased acid generation. In conclusion this study emphasizes the importance of regular monitoring of serum bicarbonate levels in our dialysis patients and the need for adjusting the dialysate bicarbonate concentrations accordingly.
\end{abstract}

Keywords: Hemodialysis patients etc.

\section{Introduction}

Dialysate bicarbonate concentration used for maintenance hemodialysis has not changed notably for past many years. Hemodialysis patients are exposed to both the bicarbonate from the base concentrate (30 - 40 $\mathrm{mEq} / \mathrm{L})$, and thebicarbonate generated from acetate in the acid concentrate. After the long interdialyticperiod serum bicarbonate concentrations fall to $19-22 \mathrm{mEq} / \mathrm{L}$ in most patients ${ }^{1}$. By the end of the dialysis session, serum bicarbonate level is about 4-7 $\mathrm{mEq} / \mathrm{L}$ less than the dialysate bicarbonate concentration. The studies using DOPPS (Dialysis Outcomes and Practice Patterns Study) database showed that mortality risk increases only for predialysis bicarbonate values $<19 \mathrm{mEq} / \mathrm{L}$. But the studies with the DaVita database showed an increased risk for levels $<20 \mathrm{mEq} / \mathrm{L}$ in some populations and $22 \mathrm{mEq} / \mathrm{L}$ in others. NKF-KDOQI (National Kidney Foundation-Kidney Disease Outcomes Quality Initiative) guidelines still recommend increasing predialysis bicarbonate to $>22$ $\mathrm{mEq} / \mathrm{L}$ based on evidence that it improves muscle and bone metabolism with correction of acidosis. This recommendation remains controversial because the

*Corresponding author's ORCID ID: 0000-0001-7147-8691, DOI: https://doi.org/10.14741/ijmcr/v.6.2.7 mortality appears to be lowest in populations with predialysis bicarbonate values of $20-22 \mathrm{mEq} / \mathrm{L}$.

$A$ recent study using the DOPPS database gives an opinion that increasing the dialysate bicarbonate concentration increases the risk of all cause mortality regardless of the predialysis serum bicarbonate levels. Targeting a high bicarbonate target may not be prudent because of the chance of higher fluctuations in the bicarbonate \& $\mathrm{pH}$ levels, volume overload and vascular calcification, which can increase mortality. The aim of the current study was to find out whether our dialysis population attained the KDOQI recommended predialysis bicarbonate target of $22 \mathrm{mEq} / \mathrm{L}$ and assess its correlation to various clinical and biochemical parameters.

\section{Aim}

\section{Primary Objective}

To assess whether maintenance hemodialysis patients in our institution are achieving adequate predialysis serum bicarbonate levels.

\section{Secondary Objective}

To assess the correlation of predialysis serum bicarbonate with other biochemical and clinical parameters. 


\section{Materials and Methods}

This cross-sectional study included 50 patients undergoing maintenance hemodialysis in Government Medical College, Thiruvananthapuram, Kerala. Out of the 50 patients, 26 were receiving hemodialysis from the Super Speciality Block (SSB) facility directly under the Department of Nephrology and 24 were under the facility receiving aid from the Karunya Benevolent fund by the Kerala government

\section{Inclusion Criteria}

1.Patients undergoing maintenance hemodialysis in Government Medical College, Thiruvananthapuram ( SSB or Karunya).

2.Patients on maintenance hemodialysis for more than 3 months.

3.Patients using ArterioVenous Fistula (AVF) as dialysis access.

\section{Exclusion Criteria}

1.Patients on MHD less than 3 months.

2.Patients with catheter as hemodialysis access.

2.Patients with ongoing infections.

All the patients gave informed consent. Patients were on either twice or thrice weekly maintenance hemodialysis. Patients in the SSB facility were dialysed with the Fresenius $4008 \mathrm{~S}$ hemodialysis device and those under Karunya facility were using the B Braun Dialog ${ }^{+}$dialysis machine. All the patients were using the Fresenius F6 $\left(1.3 \mathrm{~m}^{2}\right)$ Polysulfonedialyser. Dialysate flow rate was $500 \mathrm{ml} / \mathrm{min}$ for all patients. Both centres used fixed nonindividualized dialysate bicarbonate for all patients. The Fresenius machine had dialysate bicarbonate set at $32 \mathrm{mEq} / \mathrm{L}$ and the B Braun machine at 35 $\mathrm{mEq} / \mathrm{L}$.Bicarbonate solutions were prepared fresh before each dialysis.

Serum bicarbonate levels measured by venous blood gas analysis pre and post dialysis on the day with longest interdialytic period. Other blood investigations were also done on the same day. Blood gas analysis was done using the ABL80 FLEX analyzer.

\section{Statistical Analysis}

Quantitative variables were expressed in mean \pm standard deviation. Qualitative variables were expressed in frequency distribution. Comparison between groups of qualitative variables were analysed by chi- square test. Comparison of quantitative variables between two groups were analysed by independent sample $t$ test and that of more than two groups was analysed by ANOVA. Correlation between two quantitative variables were analysed by Pearson correlation. A multivariate analysis of linear regression was performed on variables which were found to have significant association with predialysis bicarbonate level during univariate analysis. A p value of < 0.05 was taken as the level of significance. Data analysis was performed using the SPSS ver 17.0 software.

\section{Results}

Baseline characteristics of the study group are summarized in Table1. Table 2 shows the baseline characteristics between the SSB group and Karunya group. The mean age of the study group was $53.5 \pm$ 9.3 years(range 30 to 72 years). Age distribution is given in Figure 1. There were 40 males and 10 females. The etiology of renal disease were diabetic nephropathy (40\%), chronic glomerulonephritis (22\%), unknown (14\%), polycystic kidney disease (8\%), reflux nephropathy (8\%), chronic tubulointerstitial disease (4\%) and ischemic nephropathy (4\%)(Figure1).

Table 1. Baseline patient characteristics

\begin{tabular}{|c|c|}
\hline Variable & Mean $\pm \mathrm{sd}$ \\
\hline Age (year) & $53.5 \pm 9.3$ \\
\hline Duration on MHD (months) & $27.1 \pm 21.6$ \\
\hline RUO (ml/day) & $313.6 \pm 199.5$ \\
\hline Avg BFR (mL/mt) & $250.0 \pm 17.5$ \\
\hline Post HD Weight (kg) & $55.7 \pm 10.5$ \\
\hline BMI $\left(\mathrm{kg} / \mathrm{m}^{2}\right)$ & $20.8 \pm 3.2$ \\
\hline Interdialytic Weight gain (kg) & $4.2 \pm 6.4$ \\
\hline Hemoglobin (gm/dl) & $8.2 \pm 1.5$ \\
\hline B.Urea $(\mathrm{mg} / \mathrm{dl})$ & $115.9 \pm 30.6$ \\
\hline S. Creatinine (mg/dl) & $9.7 \pm 2.4$ \\
\hline S.Sodium (mEq/L) & $139.5 \pm 4.3$ \\
\hline S.Potassium (mEq/L) & $5.3 \pm 0.8$ \\
\hline S.Calcium (mg/dl) & $8.2 \pm 0.9$ \\
\hline S.Phosphorus (mg/dl) & $5.7 \pm 1.4$ \\
\hline S. Uric acid (mg/dl) & $5.97 \pm 1.19$ \\
\hline T. Protein (g/dl) & $6.5 \pm 0.6$ \\
\hline S. Albumin (g/dl) & $3.6 \pm 0.4$ \\
\hline S.Ferritin (ng/ml) & $578.4 \pm 481.4$ \\
\hline T.Cholesterol (mg/dl) & $160.3 \pm 46.4$ \\
\hline PreHD Bicarbonate (mEq/L) & $19.0 \pm 4.2$ \\
\hline PostHD Bicarbonate (mEq/L) & $24.3 \pm 4.0$ \\
\hline PreHD SBP $(\mathrm{mm}$ of $\mathrm{Hg})$ & $158.6 \pm 18.4$ \\
\hline PreHD DBP $(\mathrm{mm}$ of $\mathrm{Hg})$ & $83.2 \pm 12.2$ \\
\hline
\end{tabular}

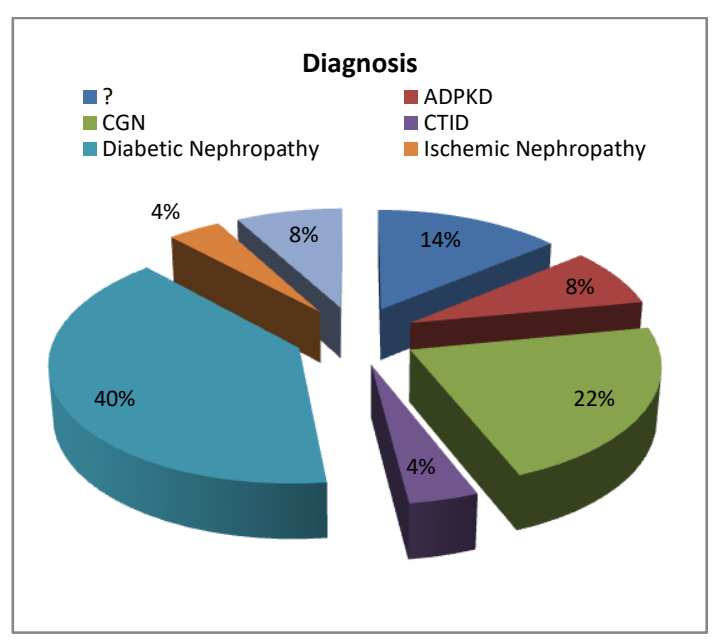

Figure 1.Etiology of renal disease 
Table 2. Baseline characteristics between SSB and Karunya groups

\begin{tabular}{|c|c|c|c|c|}
\hline \multirow{2}{*}{ Variable } & \multicolumn{2}{|c|}{ Karunya $(\mathrm{N}=24)$} & \multicolumn{2}{|c|}{ SSB $(N=26)$} \\
\hline & mean & sd & mean & sd \\
\hline Age (years) & 55.71 & 8.16 & 51.38 & 9.93 \\
\hline Duration of HTN (years) & 10.38 & 7.60 & 8.28 & 6.15 \\
\hline Duration on MHD (months) & 22.38 & 12.15 & 31.42 & 27.22 \\
\hline $\mathrm{RUO}$ (ml/day) & 329.17 & 164.13 & 299.23 & 229.78 \\
\hline Avg BFR (ml/min) & 250.00 & 14.74 & 250.00 & 20.00 \\
\hline Post HD Weight (kg) & 55.04 & 9.01 & 56.29 & 11.93 \\
\hline $\operatorname{BMI}\left(\mathrm{kg} / \mathrm{m}^{2}\right)$ & 20.42 & 2.84 & 21.12 & 3.54 \\
\hline $\begin{array}{l}\text { Interdialytic weight gain } \\
(\mathrm{kg})\end{array}$ & 5.22 & 9.14 & 3.26 & 0.79 \\
\hline Hemoglobin*(gm/dl) & 7.45 & 0.84 & 8.89 & 1.59 \\
\hline B.Urea( $\mathrm{mg} / \mathrm{dl})$ & 112.92 & 31.83 & 118.73 & 29.86 \\
\hline S. Creatinine (mg/dl) & 9.84 & 2.02 & 9.59 & 2.80 \\
\hline S.Sodium (mEq/L) & 139.42 & 4.10 & 135.23 & 25.27 \\
\hline S.Potassium*(mEq/L) & 4.96 & 0.71 & 5.54 & 0.78 \\
\hline S.Calcium (mg/dl) & 8.00 & 0.91 & 8.30 & 0.97 \\
\hline S.Phosphorus* & 4.92 & 1.00 & 6.40 & 1.30 \\
\hline S. Uric acid(mg/dl) & 6.31 & 0.88 & 5.65 & 1.35 \\
\hline T. Protein(g/dl) & 6.30 & 0.50 & 6.74 & 0.59 \\
\hline S. Albumin(g/dl) & 3.55 & 0.33 & 3.62 & 0.38 \\
\hline S.Ferritin*(ng/ml) & 722.73 & 566.59 & 445.12 & 346.97 \\
\hline CRP (mg/dl) & 0.53 & 0.45 & 1.42 & 1.79 \\
\hline T.Cholesterol (mg/dl) & 158.88 & 48.98 & 161.54 & 44.86 \\
\hline $\begin{array}{c}\text { Predialysis } \\
\text { Bicarbonate }^{*}(\mathrm{mEq} / \mathrm{L}) \\
\end{array}$ & 21.63 & 3.60 & 16.57 & 3.07 \\
\hline $\begin{array}{l}\text { Postdialysis Bicarbonate* } \\
\text { (mEq/L) }\end{array}$ & 27.28 & 3.46 & 21.52 & 2.05 \\
\hline PreHD pH & 7.37 & 0.04 & 7.35 & 0.05 \\
\hline Post HD pH & 7.44 & 0.05 & 7.45 & 0.04 \\
\hline PreHD SBP $(\mathrm{mm}$ of $\mathrm{Hg})$ & 158.75 & 17.27 & 158.46 & 19.74 \\
\hline PreHD DBP $(\mathrm{mm}$ of $\mathrm{Hg}$ ) & 82.50 & 5.32 & 83.85 & 6.27 \\
\hline PostHD SBP $(\mathrm{mm}$ of $\mathrm{Hg})$ & 160.58 & 21.05 & 153.85 & 25.78 \\
\hline Post DBP (mm of $\mathrm{Hg}$ ) & 82.08 & 5.09 & 83.69 & 6.27 \\
\hline
\end{tabular}

The mean predialysis bicarbonate was $19 \pm 4.2 \mathrm{mEq} / \mathrm{L}$. The mean predialysis bicarbonate in the SSB group was $16.6 \pm 5.3 \mathrm{mEq} / \mathrm{L}$ and that in the Karunya group was $21.6 \pm$ $3.6 \mathrm{mEq} / \mathrm{L}$. Thirty six patients $(72 \%)$ had predialysis bicarbonate $<22 \mathrm{mEq} / \mathrm{L}$ and 14 patients $(28 \%)$ had $>22$ $\mathrm{mEq} / \mathrm{L}$ ( Table3). Nineteen patients (38\%) had bicarbonate level $<17 \mathrm{mEq} / \mathrm{L}$ and 5 patients $(10 \%)$ had level $>25 \mathrm{mE} / \mathrm{L}$ (Figure 2).

Table 3. Difference in serum bicarbonate between SSB and Karunya group

\begin{tabular}{|c|c|c|c|c|c|c|c|c|c|}
\hline \multirow{3}{*}{$\begin{array}{l}\text { Hemodialys } \\
\text { is centre }\end{array}$} & \multicolumn{4}{|c|}{ Pre HD Bicarbonate } & \multirow{2}{*}{\multicolumn{2}{|c|}{ Total }} & \multirow{3}{*}{${ }^{2} \times$} & \multirow{3}{*}{ 峁 } & \multirow{3}{*}{ e } \\
\hline & \multicolumn{2}{|c|}{$\begin{array}{c}\leq 22 \\
(\mathrm{mEq} / \mathrm{L})\end{array}$} & \multicolumn{2}{|c|}{$\begin{array}{c}>22 \\
(\mathrm{mEq} / \mathrm{L})\end{array}$} & & & & & \\
\hline & $\mathrm{N}$ & $\%$ & $N$ & $\%$ & $\mathrm{~N}$ & $\%$ & & & \\
\hline Karunya & 11 & 45.8 & 13 & 54.2 & 24 & 100 & \multirow{3}{*}{$\begin{array}{l}\stackrel{n}{\sigma} \\
\stackrel{\leftrightarrow}{\sim}\end{array}$} & \multirow{3}{*}{$\rightarrow$} & \multirow{3}{*}{ ठ̊ } \\
\hline SSB & 25 & 96.2 & 1 & 3.8 & 26 & 100 & & & \\
\hline Total & 36 & 72 & 14 & 28 & 50 & 100 & & & \\
\hline
\end{tabular}

The mean postdialysis bicarbonate was $24.3 \pm 4.0 \mathrm{mEq} / \mathrm{L}$. The mean postdialysis bicarbonate in the SSB group was $21.5 \pm 2.1 \mathrm{mEq} / \mathrm{L}$ and that in the Karunya group was 27.3 $\pm 3.5 \mathrm{mEq} / \mathrm{L}$.

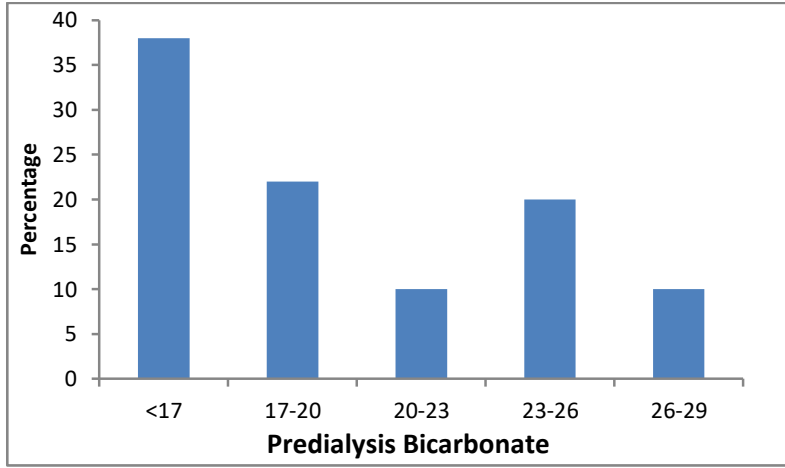

Figure 2. Levels of predialysis serum bicarbonate

There was no significant difference between diabetic and nondiabetic group with regard to predialysis bicarbonate levels. The etiology of renal disease had no significant relation to predialysis bicarbonate. Seven out of the 50 patients were on thrice weekly dialysis. There was no statistically significant difference between the 2/week and 3/week hemodialysis groups in relation to predialysis bicarbonate values. Similarly there was no significant relation for predialysis bicarbonate with intake of calcium containing phosphate binders, sevelamer or oral sodium bicarbonate supplements.

A negative correlation was obtained for predialysis bicarbonate levels with total protein and serum phosphorus (Figure 3 ) by Pearson correlation (Table 4). A positive Pearson correlation was seen for predialysis bicarbonate with predialysis $\mathrm{pH}$ and post dialysis bicarbonate levels. By multivariate correlation, a negative correlation was obtained for BMI, serum uric acid, serum ferritin and total protein withpredialysis bicarbonate levels (Table 4).

Table 4. Correlation between serum bicarbonate and relevant clinical \& laboratory variables

\begin{tabular}{|c|c|c|}
\hline Variables & Pearson correlation & Multivariate correlation \\
\hline Age (years) & 0.18 & .014 \\
\hline $\begin{array}{l}\text { Duration on MHD } \\
\text { (months) }\end{array}$ & -0.158 & .132 \\
\hline RUO (ml/day) & -0.088 & .070 \\
\hline Avg BFR (ml/min) & -0.029 & .096 \\
\hline $\mathrm{BMI}\left(\mathrm{kg} / \mathrm{m}^{2)}\right.$ & -0.26 & $-.453^{\mathrm{a}}$ \\
\hline $\begin{array}{c}\text { Interdialytic Weight } \\
\text { gain }(\mathrm{kg})\end{array}$ & 0.059 & -.140 \\
\hline B.Urea $(\mathrm{mg} / \mathrm{dl})$ & -0.114 & -.298 \\
\hline S. Creatinine $(\mathrm{mg} / \mathrm{dl})$ & -0.217 & .314 \\
\hline S.Calcium (mEq/L) & 0.019 & -.273 \\
\hline S.Phosphorus(mg/dl) & $-0.477^{a}$ & .241 \\
\hline S. Uric acid (mg/dl) & 0.035 & $-.561^{\mathrm{a}}$ \\
\hline T. Protein (gm/dl) & $-0.325^{a}$ & $-.394^{\mathrm{a}}$ \\
\hline S. Albumin (gm/dl) & -0.169 & .119 \\
\hline S.Ferritin (ng/ml) & 0.04 & $-.512^{a}$ \\
\hline $\mathrm{CRP}(\mathrm{mg} / \mathrm{dl})$ & -0.036 & .243 \\
\hline T.Cholesterol (mg/dl) & 0.144 & -.018 \\
\hline $\begin{array}{c}\text { PostHD Bicarbonate } \\
(\mathrm{mEq} / \mathrm{L})\end{array}$ & $0.825^{b}$ & $.803^{\mathrm{b}}$ \\
\hline PreHD pH & $0.605^{b}$ & $.535^{\mathrm{b}}$ \\
\hline $\begin{array}{c}\text { PreHD SBP (mm of } \\
\mathrm{Hg} \text { ) }\end{array}$ & -0.108 & -.215 \\
\hline $\begin{array}{c}\text { PreHD DBP (mm of } \\
\mathrm{Hg})\end{array}$ & 0.056 & .233 \\
\hline
\end{tabular}




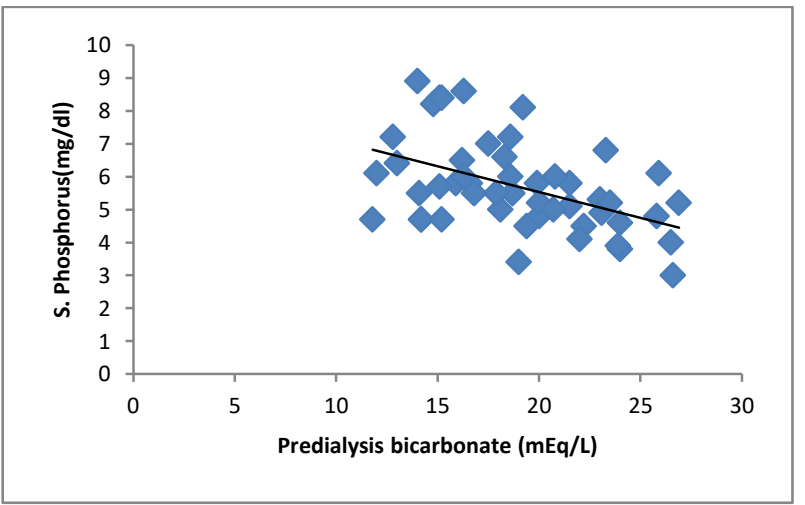

Figure 3. Negative correlation of serum bicarbonate with serum phosphorus

\section{Discussion}

We found that only $28 \%$ of our study population achieved the predialysis bicarbonate target of $>22 \mathrm{mEq} / \mathrm{L}$ recommended by $\mathrm{KDOQI}^{2}$. The mean predialysis bicarbonate level in our population was $19 \pm 4.2 \mathrm{mEq} / \mathrm{L}$, which was lower when compared to DaVita United States value of $21.7 \pm 2.9 \mathrm{mE} / \mathrm{L}^{3}$. Unlike our patients (only $14 \%$ were on 3/week dialysis), the DaVita group and DOPPS (Dialysis Outcomes and Practice Patterns Study) group were on 3/week dialysis ${ }^{3,4}$ with an expected higher bicarbonate level.Studies have shown that very low predialysis serum bicarbonate $(<17 \mathrm{mEq} / \mathrm{L})$ should be corrected. But the target serum bicarbonate level to be attained still remains controversial.

Age or sex didnot have an impact on predialysis bicarbonate values ${ }^{3}$. The etiology of renal disease had little effect on the bicarbonate level. As in our population, the dialysis vintage had no correlation with predialysis bicarbonate level in the previous studies ${ }^{3}$. Though the number of patients on thrice weekly dialysis was less (14\%), a statistically significant difference was not obtained between the twice weekly and thrice weekly dialysis groups. Theoretically a higher serum bicarbonate levels would be expected in patients receiving thrice weekly dialysis due to better nourishment of bicarbonate stores. Only $18 \%$ of the patients were taking oral sodium bicarbonate supplementation, but they did not show a statistically significant higher serum bicarbonate levels.

We observed a statistically significant difference in the predialysis serum bicarbonate between the SSB and Karunya group (Table 5). This may be partly explained by the higher dialysate bicarbonate concentration (35.3 $\mathrm{mEq} / \mathrm{L}$ ) used in the Karunya group when compared to the SSB dialysate bicarbonate ( $32 \mathrm{mEq} / \mathrm{L}$ ).

A negative correlation was obtained for predialysis bicarbonate levels with BMI, total protein, serum uric acid, serum phosphorus and serum ferritin. Serum bicarbonate level is expected to be lower in patients with better nutrition, indicating an increased acid generation from increased protein intake. There lies an inverse correlation between serum bicarbonate level and nutrional status. Total protein, serum albumin, uric acid and serum phosphorus can be used as markers of better nutrition. As in previous studies by Gao et $\mathrm{al}^{5}$ and Leavey et $\mathrm{al}^{6}$, we also noted an inverse correlation between BMI, total protein, serum phosphorus, serum uric acid and serum ferritin levels. This suggests that a higher protein intake may lead to a lower serum bicarbonate at the start of the subsequent dialysis session.A higherpredialysisserum bicarbonate level may be a surrogate of inadequate dietary protein intake ${ }^{7}$. The SSB group had better nutritional parameters like haemoglobin, total protein, uric acid and serum phosphorus levels $(p<0.05)$. This could partly explain the lower serum bicarbonate level in the SSB group, apart from the lower dialysate bicarbonate concentration in the SSB patients.

Thirty eight percentage of the study population had bicarbonate level $<17 \mathrm{mEq} / \mathrm{L}$ and $10 \%$ had level $>25 \mathrm{mE} / \mathrm{L}$. An analysis of a large cohort by Lowrie et al ${ }^{4}$ found that an association between serum bicarbonate and mortality was J-shaped, in that the death was higher if the bicarbonate level was either $<17.5$ or $>25 \mathrm{mEq} / \mathrm{L}$. Though some amount of metabolic acidosis can be explained by the better nutrition, a serum bicarbonate level $<17 \mathrm{mEq} / \mathrm{L}$ definitely requires correction.

Our study had several limitations. Size of our study population was small because it was conducted in a single centre. Also the baseline nutritional parameters of our patients were poor, probably because the majority belonged to the poor socioeconomic strata, ours being a Government institution.Majority of the patients were on twice weekly hemodialysis, which may be inadequate to replenish the bicarbonate stores.

\section{Conclusion}

A high number of hemodialysis patients did not achieve even a serum bicarbonatelevelof $>20 \mathrm{mEq} / \mathrm{L}$ and a few hadpredialysisalkalemia. Health care providers must be aware of the bicarbonate settings of individual dialysis machines and the details of dialysate preparations for their machines. An individualized approach of assessing each patient in terms of his nutrition, oral bicarbonate supplements and dialysate bicarbonate concentration is the need of the hour. Nephrologists need to assess their patients serum bicarbonate values regularly and adjust their required dialysate buffer base content accordingly.

\section{Disclosures}

The authors of this study have no conflicts of interest or financial disclosures.

\section{References}

[1]. PanupongLisawat, MD, and F. John Gennari, MD: Approach to the Hemodialysis Patient With an Abnormal Serum Bicarbonate Concentration. Am J Kidney Dis. 2014 Jul;64 (1):151-5 
[2]. NK Foundation: Clinical practice guidelines for nutrition in chronic renal failure. Am J Kidney Dis 35(suppl 2):S1-S140, 2000

[3]. Dennis Y. Wu, Christian S. Shinaberger, Deborah L. Regidor, Charles J. McAllister, Joel D. Kopple, and KamyarKalantarZadeh: Association between Serum Bicarbonate and Death in Hemodialysis Patients: Is It Better to Be Acidotic or

[4]. Alkalotic?Clin J Am SocNephrol1: 70-78, 2006

[5]. Lowrie EG, Lew NL: Death risk in hemodialysis patients: The predictive value of commonly measured variables and an evaluation of death rate differences between facilities. Am J Kidney Dis 15: 458-482, 1990
[6]. Gao H, Lew SQ, Bosch JP: Moderate metabolic acidosis andits effects on serum parameters in hemodialysis patients.Nephron 86: 135-138, 2000

[7]. Leavey SF, Strawderman RL, Young EW, Saran R, Roys E, Agodoa LY, Wolfe RA, Port FK: Cross-sectional and longitudinal predictors of serum albumin in hemodialysis patients. Kidney Int58: 2119-2128, 2000

[8]. Joline L. T. Chen and KamyarKalantar-Zadeh: Is an Increased Serum Bicarbonate Concentration during Hemodialysis Associated with an Increased Risk of Death? Seminars in Dialysis - Vol 27, No 3 (May-June) 2014 pp. 259-262 